\title{
Choline Dehydrogenase, Mitochondrial
}

National Cancer Institute

\section{Source}

National Cancer Institute. Choline Dehydrogenase, Mitochondrial. NCI Thesaurus. Code C104898.

Choline dehydrogenase, mitochondrial (594 aa, $\sim 65 \mathrm{kDa}$ ) is encoded by the human CHDH gene. This protein is involved in the conversion of choline to betaine. 